\title{
Dugoročno praćenje duboke stimulacije mozga putem globus pallidus u generaliziranoj distoniji - prikaz slučaja
}

\section{Long term tracking of pallidal deep brain stimulation used in generalized dystonia - case report}

\author{
Ena Šukunda ${ }^{1^{*}}$, Vladimira Vuletić ${ }^{1}$, Fadi Almahariq ${ }^{2}$, Darko Chudy ${ }^{2}$
}

Sažetak. Cilj: Generalizirana distonija karakterizirana je nevoljnim kontrakcijama mišića koje dovode do pojave abnormalnog držanja i ponavljajućih pokreta. Duboka stimulacija mozga (engl. Deep Brain Stimulation, DBS) učinkovita je u distoniji otpornoj na lijekove, međutim, postoji manjak radova o dugoročnom učinku. Cilj rada je prezentirati dugoročni učinak primjene DBS-a kod pacijenata s generaliziranom distonijom. Prikaz slučaja: Pacijent je 29-godišnji muškarac s generaliziranom distonijom. Nakon rođenja primijećena je faciopareza po perifernom tipu, što je bilo pripisano cerebralnoj paralizi. Prvi simptomi, problemi s pisanjem zbog grčenja ruke, primijećeni su sa sedam godina. S petnaest godina primijećeni su problemi u govoru i pogoršanje distonije ruke. Distonične kretnje i držanje postupno se pogoršavalo, uzrokujući probleme $s$ hodanjem i narušavajući kvalitetu života pacijenta. Simptomi se nisu popravljali unatoč primjeni farmakoterapije i kada je pacijent imao dvadeset i jednu godinu implantirane su mu elektrode u bazalne ganglije, što je drastično poboljšalo distonične kretnje, držanje i hod. Nakon operacije, unatrag osam godina, pacijent je redovito praćen, elektrode su reprogramirane uz kontinuiranu fizikalnu i terapiju govora. $U$ dva navrata nastupio je povratak kliničke slike radi ispražnjene baterije neurostimulatora koja je prvi put zamijenjena nepunjivom, a drugi put punjivom baterijom, što je dovelo do potpunog oporavka. Zaključak: Idiopatska distonija često je neprepoznata. lako je DBS sigurna i učinkovita metoda, nije dovoljno korištena za liječenje distonije otporne na lijekove. Ovaj slučaj pokazao je perzistentan i izvrstan učinak DBS-a na generaliziranu distoniju i pacijentovu kvalitetu života kroz duži vremenski period.

Ključne riječi: distonija; duboka stimulacija mozga; dugoročni učinak

Abstract. Aim: Generalized dystonia is characterized by involuntary muscle contractions leading to abnormal postures and repetitive movements. Deep brain stimulation (DBS) is effective in medication-refractory dystonia, but there is a lack of studies about long-term effect. The goal of this case report is to show long-term effect in a patient with generalized dystonia treated with DBS. Case report: We present a case of a 29 -years-old patient with isolated generalized dystonia. At birth, peripheral facial palsy was noticed which was attributed to cerebral paralysis. First symptoms noticed at 7-years-old were problems with handwriting due to hand spasms. At 15 , speech problems started and dystonia of his hand worsened. Then, dystonic movements and postures gradually expanded causing walking problems and poor quality of life. Symptoms did not improve with available medications and at the age of 21 electrodes were implanted into basal ganglia which extremely improved his dystonic movements, posture and gait. After the surgery, during these eight years, the patient was regularly controlled, electrodes were reprogramed with continuous physical and speech therapy. Twice he presented with returned complete clinical presentation due to the empty battery of the neurostimulator that was replaced first with a non-rechargeable and then with a rechargeable battery leading to complete improvement. Conclusion: Idiopathic dystonia is often unrecognized. Although, DBS is a safe and effective method, it is not used enough for treating medication-refractory dystonia. Our case has shown persistent and excellent effect of DBS on generalized dystonia and patients' quality of life over a long period of time.

Key words: deep brain stimulation; dystonia; long-term effect

\author{
${ }^{1}$ Medicinski fakultet Sveučilišta u Rijeci, \\ Rijeka \\ ${ }^{2}$ Zavod za neurokirurgiju, KB Dubrava, \\ Zagreb
}

\author{
*Dopisni autor: \\ Ena Šukunda \\ Medicinski fakultet Sveučilišta u Rijeci \\ Braće Branchetta 20, 51000 Rijeka \\ e-mail: ena.sukunda@gmail.com
}




\section{UVOD}

Distonija je poremećaj pokreta karakteriziran neprekidnim ili isprekidanim kontrakcijama mišića koje uzrokuju abnormalne, često ponavljajuće kretnje, držanje ili oboje ${ }^{1}$. Poremećaj može rezultirati teškom invalidnošću i znatno narušenom kvalitetom života kod pacijenata². Injekcije botulinum toksina predstavljaju lijek izbora kod fokalne distonije, međutim, pacijenti zahvaćeni segmentalnim ili generaliziranim oblicima često ne odgo-

Kada dostupna medikamentozna terapija ne pomaže, bilateralna duboka stimulacija mozga putem globus pallidus smatra se sigurnim i učinkovitim rješenjem kod pacijenata s izoliranom naslijeđenom ili idiopatskom segmentalnom ili generaliziranom distonijom.

varaju optimalno na medikamentoznu terapiju ${ }^{3}$. Kada dostupna medikamentozna terapija ne pomaže, bilateralna duboka stimulacija mozga (engl. Deep Brain Stimulation, DBS) putem globus pallidus smatra se sigurnim i učinkovitim rješenjem, pogotovo kod pacijenata s izoliranom naslijeđenom ili idiopatskom segmentalnom ili generaliziranom distonijom ${ }^{2}$. Postoji manjak radova koji proučavaju dugoročni učinak DBS-a na distoniju, ali s obzirom na navedeno, DBS treba biti uzet u obzir kod odabira terapije za distoniju otpornu na lijekove. Cilj rada je prikazati slučaj pacijenta koji boluje od generalizirane distonije liječene DBS-om putem globus pallidus praćen kroz vremenski period od osam godina.

\section{PRIKAZ SLUČAJA}

Dvadesetjednogodišnji pacijent bio je zaprimljen u kolovozu 2011. godine na Odjel za neurokirurgiju Kliničke bolnice Dubrava u Zagrebu radi operacijskog liječenja. Tegobe su počele kada je pacijent imao sedam godina, po upisu u školu, kada je zamijećeno da ima problema s pisanjem jer mu se „grčila“ ruka. S petnaest godina tegobe postaju izraženije u vidu distoničkih kretnji desne ruke s vanjskom rotacijom, distonije trupa i donjih ekstremiteta, otežanog govora i hoda. Pacijent je do tada od lijekova uzimao biperiden (15 $\mathrm{mg} /$ dan) i baklofen (2 x 5-10 mg/dan).
Prilikom prijama pacijent je bio pri svijesti, orijentiran, dizartričan i disfoničan. Od ranije je bila prisutna faciopareza po perifernom tipu i hiperkineze jezika. Kod pacijenta je bila prisutna i generalizirana distonija, jače izražena lijevo, posebice pri hodu, i povišen tonus po tipu rigora. Pacijent je bio funkcionalno ovisan zbog teške onesposobljenosti, socijalno izoliran stalnim boravkom kod kuće i bez planova za budućnost. Operiran je u rujnu 2011. godine. U preoperacijskoj pripremi snimljena je magnetska rezonancija (MR) mozga na kojoj su se vizualizirale jezgre bazalnih ganglija globus palidus. Učinjena je trepanacija parijetalne kosti obostrano te su se stereotaksijskim navođenjem uvele elektrode $u$ stražnji dio globus pallidus, pars interna obostrano. Operacija je protekla bez komplikacija te je pacijent nakon operacije bio bez novonastalog neurološkog deficita. Uključenjem neurostimulatora nastupilo je poboljšanje u vidu opuštanja muskulature trupa te poboljšanja orofacijalnih diskinezija. Na odjelu je bila započeta fizikalna terapija i rehabilitacija te je snimljen kontrolni MR mozga na kojem nije bilo znakova ishemije ili krvarenja. Pacijentu su parametri stimulacije bili podešeni na 1,7 V lijevo i 1,1 V desno uz korekciju terapije baklofenom (3 x $10 \mathrm{mg} / \mathrm{dan}$ ). Dva tjedna nakon operacije pacijentu je zbog povratka simptoma bila učinjena promjena parametara stimulacije i to na 1,8 V lijevo i 1,3 V desno. Na kontroli tri mjeseca nakon operacije navodio je da se osjeća dobro i da ima poboljšanje motorike desnih ekstremiteta, osobito ruke s kojom je tada mogao samostalno pisati. Također, navodio je da je puno samostalniji i da ima kvalitetniji život nego prije operacije. Nakon pet mjeseci zbog pojave grča u desnoj ruci parametri su ponovno bili promijenjeni i to desno na 3,2,V i lijevo na 2,5,V. Nakon četiri mjeseca uz promjenu parametara stimulacije na 3,8,V desno i 2,6,V lijevo bila je uvedena stimulacija strujom u fizikalnu terapiju, a nakon idućih pet mjeseci uz ponovno reprogramiranje uvedene su i vježbe kod logopeda. Godinu dana nakon implantacije elektroda uspjeh terapije bio je evidentan, izuzev poteškoća u govoru, radi čega je pacijent bio upućen u referentnu logopedsku ustanovu. Pacijent je bio samostalan, s minimalnom onesposobljenosti, 
izašao iz socijalne izoliranosti i s planovima za daljnje školovanje i budućnost. Godinu i osam mjeseci nakon operacije kod pacijenta su se ponovno javile poteškoće u govoru te mioklonizmi na lijevim ekstremitetima uz otežan hod. Ispitivanjem uređaja utvrđeno je da se baterija neurostimulatora ispraznila te je bila zamijenjena nepunjivom baterijom. Tijekom hospitalizacije pacijent je primao ceftriakson $(2 \times 2 \mathrm{~g})$ te je kod otpusta bio afebrilan. Nakon operacije stimulacija se postavila na 3,5 V desno i 3,7 V lijevo. Na stimulaciju je kod pacijenta dolazilo do vidljivog kliničkog poboljšanja. Dvije godine nakon zamjene neurostimulatora ponovno dolazi do vraćanja simptoma generalizirane distonije, pa je pacijent bio ponovno hospitaliziran zbog dekapacitirane baterije, koja je ovaj put zamijenjena punjivom baterijom. Nakon zahvata i reprogramiranja stimulacija ponovno dolazi do vidljivog kliničkog poboljšanja, potpune neovisnosti pacijenta i poboljšanja kvalitete života. Pacijent je na sljedećih nekoliko kontrola navodio nevoljne pokrete desnog ramena, međutim, zbog već prisutnih visokih voltaža reprogramiranje se nije preporučilo u tom trenutku, pa su se nastavile kontrole uz redovitu fizikalnu terapiju. Ipak, reprogramiranje je bilo učinjeno nekoliko puta u iduće dvije godine zbog perzistentnih poteškoća u hodu desnom stranom i nevoljnih pokreta desne ruke i ramena. Šest godina i devet mjeseci nakon implantacije elektroda pacijent se hospitalizira radi potrebe za detaljnijom analizom, kao i modificiranja neurostimulacije. Tijekom hospitalizacije učinjeno je nekoliko promjena parametara stimulacije do pojave regresije distoničkih pokreta i grča desne noge i desnog ramena. Četiri mjeseca poslije pacijent je bio hospitaliziran radi daljnje dijagnostičke obrade. Učinjen je radiogram glave, vrata $i$ prsnog koša te MR mozga, kojima je utvrđen uredan položaj elektroda i elektrostimulatora. Osam godina nakon postavljanja stimulatora kliničko poboljšanje je i dalje prisutno $u$ istoj mjeri kao i funkcionalna neovisnost i bolja kvaliteta života pacijenta.

\section{RASPRAVA}

Uvođenjem DBS-a kao opcije liječenja esencijalnog tremora otpornog na lijekove prije tridesetak godina otkrilo se po prvi put da dugotrajno implantirani uređaji u mozak imaju potencijal modulirati neurološku funkciju uz iznenađujuće nizak morbiditet. Nakon nekog vremena, isti potencijal utvrđen je i u liječenju Parkinsonove bolesti i distonije 4 .

lako je patofiziologija generalizirane ili segmentalne distonije slabo razjašnjena, uočeno je da jezgre bazalnih ganglija globus pallidus pars interna imaju ključnu ulogu. Opažanja tijekom palidotomija otkrila su abnormalne uzorke opetovane

Osam godina iza postavljanja stimulatora kliničko poboljšanje je i dalje prisutno u istoj mjeri kao i funkcionalna neovisnost i bolja kvaliteta života pacijenta. $\mathrm{S}$ obzirom na navedeno, preporučujemo raniju upotrebu DBS-a kod distonije otporne na lijekove kod pacijenata sa znatno narušenom kvalitetom života.

aktivnosti u globus pallidus kod pacijenata s distonijom ${ }^{5}$.Trenutno prva linija liječenja distonije uključuje simptomatsku terapiju od koje su najučinkovitiji oralni antikolinergični lijekovi za generaliziran i intramuskularno primijenjen botulinum neurotoksin za fokalnu distoniju, međutim, neki pacijenti ne reagiraju na navedenu terapiju ili ona gubi učinkovitost kroz duži vremenski period. Također, oralna farmakoterapija, pogotovo kod generalizirane distonije, često je nedostatna i ima mnogostruke nuspojave ${ }^{6}$.

DBS visoke frekvencije koji se implantira bilateralno u globus pallidus pars interna potvrđen je kao učinkovita druga linija liječenja u distoniji otpornoj na lijekove sa znatno smanjenom kvalitetom života pacijenata ${ }^{3-6}$. Ova terapija smatra se sigurnom alternativom palidotomiji zbog moguće reverzibilnosti, manje stope komplikacija kod bilateralne implantacije i veće mogućnosti prilagodbe $^{6}$. Klinički učinak podložan je promjenama koje ovise o ciljnom mjestu i parametrima stimulacije. Specifične stimulacijom izazvane nuspojave bile su opisane za svako ciljno mjesto, međutim, većinu je moguće ukloniti isključenjem stimulacije, promjenom aktivnog kontakta ili promjenom parametara stimulacije ${ }^{5}$.

U našem slučaju prikazali smo pacijenta koji je redovno i dugoročno praćen nakon implantacije 
elektroda bilateralno u globus pallidus pars interna zbog generalizirane distonije otporne na lijekove. U praćenju pacijenta sudjelovao je multidisciplinarni tim sastavljen od neurologa, neurokirurga, fizioterapeuta, logopeda itd. Naš slučaj prikazuje regresiju simptoma generalizirane distonije i nakon dužeg vremenskog perioda nakon provedene stimulacije.

\section{ZAKLJUČAK}

Duboka stimulacija mozga sigurna je i učinkovita, no nedovoljno korištena metoda za liječenje distonije otporne na lijekove. Naš slučaj pokazao je perzistentan i izvrstan učinak DBS-a na distoniju otpornu na lijekove i pacijentovu kvalitetu života kroz duži vremenski period. S obzirom na navedeno, preporučujemo raniju upotrebu DBS-a kod distonije otporne na lijekove kod pacijenata sa znatno narušenom kvalitetom života. Također, važno je kod ponovnog nastupa kompletne kliničke slike nakon implantacije elektroda pomisliti na moguću ispražnjenu bateriju neurostimulatora te je zamijeniti punjivom baterijom. Konačno, smatramo da su daljnja istraživanja dugoročnog učinka DBS-a kod pacijenata s generaliziranom distonijom otpornom na lijekove nužna zbog do sada opisanog pozitivnog učinka i radi širenja spoznaja o terapeutskom učinku navedene metode.

Izjava o sukobu interesa: Autori izjavljuju da ne postoji sukob interesa.

\section{LITERATURA}

1. Albanese A, Bhatia K, Bressman SB, DeLong MR, Fahn S, Fung VS et al. Phenomenology and classification of dystonia: a consensus update. Mov Disord 2013;28:863-73.

2. Moro E, LeReun C, Krauss JK, Albanese A, Lin JP, Autiero SW et al. Efficacy of pallidal stimulation in isolated dystonia: a systematic review and meta-analysis. Eur J Neurol 2017;24:552-60.

3. Mueller J, Skogseid IM, Benecke R, Kupsch A, Trottenberg T, Poewe $W$ et al. Pallidal deep brain stimulation improves quality of life in segmental and generalized dystonia: Results from a prospective, randomized shamcontrolled trial. Mov Disord 2008;23:131-4.

4. Skidmore FM, Rodriguez RL, Fernandez HH. Lessons learned in deep brain stimulation for movement and neuropsychiatric disorders. CNS Spectr 2006;11:521-36.

5. $\mathrm{Yu} \mathrm{H}$, Neimat JS. The treatment of movement disorders by deep brain stimulation. Neurotherapeutics 2008;5: 26-36.

6. Ortiz RM, Scheperjans F, Pekkonen E. Deep brain stimulation for dystonia in Finland during 2007-2016. BMC Neurol [Internet]. 2019;137. [cited 2019 Sep 13]. Available from: https://bmcneurol.biomedcentral.com/articles/10.1186/s12883-019-1370-y. 